\title{
A Study on the Efficiency of Financial Poverty Alleviation Funds in Guizhou Province_-Take Four National Poverty Counties in Anshun City as Example
}

\author{
Yayuan Wang ${ }^{\text {a }}$, Hongqiong Zhu ${ }^{\text {b }}$ \\ GuiZhou University of Finance and Economics, Guiyang, 550025, China. \\ a578770922@qq.com, b13078502065@126.com
}

\begin{abstract}
The financial poverty alleviation fund is the main resource input of poverty alleviation. Its efficiency directly affects the result of poverty effect. Based on present situation that financial poverty alleviation fund is facing status of increasing scale and decreasing efficiency in Huizhou province, this article aims to take four national poverty counties in Anshan as research sample, constructing qualitative and quantitative models to evaluate the efficiency of financial poverty alleviation fund. Thus to creating an objective and comprehensive evaluation of the efficiency of financial poverty alleviation fund in Guizhou Province. Finally, our analysis results suggest that: Guizhou province should further improve the evaluation mechanism of financial poverty alleviation fund, so as to improve scale and structure of financial poverty alleviation fund. Furthermore, government should improve financial poverty alleviation fund's efficiency, and service in poverty reduction in poor areas. All of those will help the goal of building an All-round Well-off Society in 2020 come true.
\end{abstract}

Keywords: The financial poverty alleviation; funds; efficiency;DEA empirical analysis.

\section{贵州省财政扶贫资金使用效率研究一一安顺市四个国定贫困县为例}

\author{
王雅媛, 朱红琼 \\ 贵州财经大学, 贵阳, 550025, 中国
}

摘 要: 财政扶贫资金是扶贫工作最主要的资源投入，其使用效率直接影响贫困治理的效果。 应对贵州省财政扶贫资金面临规模不断提高而扶贫效率递减的现状，本文以安顺市四个国定 贫困县为研究样本, 构建DEA莫氏指数和定量实证模型评价其财政扶贫资金使用效率, 并以此 推广至全省，对贵州省财政扶贫资金使用效率进行客观全面评价。最终，根据分析结果提出 建议: 贵州省应进一步完善财政扶贫资金评价考核机制, 优化财政扶贫资金规模及投向结构, 从而进一步提高财政扶贫资金使用效率，服务于贵州省贫困地区的减贫与我国2020年全面小 康社会建设目标的如期实现。

关键词：财政扶贫；资金; 效率; DEA实证分析

\section{1. 引言}

2013 年习近平总书记提出 “精准扶贫” 这一战略决策, 致力于将财政专项扶贫资金真正得到 落实，扶贫成果要被贫困群众切实享受。在精准扶贫过程中，政府扶贫资金的大力支持有助 于贫困人口不断减少。在加大财政扶贫资金投入的同时，人们也越发关注扶贫资金的减贫效 果及使用效率。早前有学者马丁. 拉瓦雷 (2007) 在扶贫研究中通过获得的数据对中国南部地 区部分贫困省份进行脱贫成效探讨，得出如下结论：中国的扶贫资金减贫率仅为 $12 \%$ 。但就 这一数据, 国内有部分学者也认为可能高估了真实的扶贫资金减贫效率。如今更多学者提出: 扶贫工作的开展不仅要帮助贫困人口实现脱贫, 同时不可忽视减贫的资金投入与最终产出是 否有效且具有持续性。 
为此, 本研究基于近年来贵州省财政扶贫实践, 以安顺市四个扶贫开发重点县为样本, 在借 鉴已有研究成果和方法的基础上致力于测度财政扶贫资金使用效率。通过构建定性及定量实 证评价模型实现对贵州省财政扶贫资金使用效率的客观全面评价, 最终提出针对性的意见及 建议。

\section{2. 贵州省贫困状况简述}

贵州是一个多民族的省份, 也是全国为数不多的贫困人口比较多的省份之一。三千九百多万 人共同生活在这个石灰岩占百分之七十以上的省份, 常年水土流失严重, 自然灾害频发。安 顺市的四个扶贫开发重点县属于安顺的特殊困难区、国定贫困县，每年共获得财政扶贫资金 占安顺市总量约 76\%, 非常具有扶贫研究的价值。因此本文选取安顺市四个扶贫开发重点县 为研究样本对其扶贫投入及成果进行深入探讨。

贵州省贫困户贫困程度以人均收入为基础定义, 如表 1 所示, 从统计数据来看, 2015 年安顺 市四个扶贫开发重点县的人均可支配收入大约为 6000 元，不到全国人均可支配收入 21966.2 元的三分之一。同时, 贵州省的人均粮食, 人均农林牧渔业增加值和人均地区生产总值均远 低于全国平均水平。

表1 全国及贵州省部分地区2015年人均收入情况

\begin{tabular}{|c|c|c|c|c|c|c|}
\hline & 全国 & 贵州 & 普定县 & 镇宁县 & 关岭县 & 紫云县 \\
\hline 人均可支配收入（元） & 21966. 20 & 13696.6 & 6116 & 5969 & 5986 & 5868 \\
\hline 人均粮食（公斤） & 453 & 334.27 & 216 & 264 & 257 & 277 \\
\hline 人均农林牧渔业增加值（元） & 7788.072 & 7758.357 & 4161.125 & 5441. 125 & 5952.045 & 6816.673 \\
\hline 人均地区生产总值（元） & 49730.25 & 16413 & 8030.69 & 10137.08 & 11375. 18 & 9218 \\
\hline 年末常住人口（万人） & 137462 & 3530 & 39.1 & 28.45 & 28.36 & 27.11 \\
\hline
\end{tabular}

从收入构成来看, 2015 年安顺市四个国定贫困县的人均农林牧渔业增加值占相应人均地区生 产总值大于 $50 \%$, 充分体现贵州扶贫重点县收入的低层次性。贫困县以农林牧渔业为主的生 产特征，也表明了贫困地区工业、服务业不发达的特征。

从 2015 年全国及部分地区人均收入表中人均粮食和人均农林牧渔业的增加值来看, 尽管四个 国定贫困县在产业收入上是以农林牧渔业为主, 但其人均粮食和人均农林牧渔业增加值均低 远于全国与贵州省的平均水平。说明贫困县存在着生产技术落后, 效率低下, 产出不高的问 题, 这个现实情况也直观反应了贫困县的落后程度。

\section{3. 贵州省财政扶贫资金使用效率实证分析}

3.1 安顺市四个重点县财政扶贫资金效率 DEA 分析

DEA 模型是从美国著名运筹学家 Charnes 与 Cooper 围绕效率评价发展出来的一种评价方式, 旨在研究涵盖 “多投入, 多产出要素” 的决策单元 DMU 的综合产出效率, 比较符合研究财政 扶贫资金的投入产出实际行为, 因此本文拟采用 DEA 莫氏指数进行测算。我们对安顺市县级 的扶贫成效主要通过观测其财政扶贫资金投入所产生的效果，考虑到指标的代表性和可获得 性, 选取 2013-2016 年安顺市四个扶贫重点县的财政扶贫资金总额为投入指标, 而产出指标 主要有地区生产总值、第一、第二、第三产业产值、农民人均纯收入等。计算结果见表 2 。 
表2 安顺市四个扶贫开发重点县Malmquist生产率指数及其分解项

\begin{tabular}{|c|c|c|c|c|}
\hline 地区 & 年份 & 综合效率 & 纯技术效率 & 规模效率 \\
\hline \multirow[t]{5}{*}{ 普定县 } & 2013 & 1 & 1 & 1 \\
\hline & 2014 & 0.335 & 0.978 & 0.342 \\
\hline & 2015 & 0.452 & 0.979 & 0.462 \\
\hline & 2016 & 0.605 & 1 & 0.605 \\
\hline & 平均值 & 0.598 & 0.98925 & 0.60225 \\
\hline \multirow[t]{5}{*}{ 镇宁县 } & 2013 & 0.264 & 0.706 & 0.374 \\
\hline & 2014 & 1 & 1 & 1 \\
\hline & 2015 & 0.375 & 0.886 & 0.423 \\
\hline & 2016 & 0.572 & 1 & 0.572 \\
\hline & 平均值 & 0.55275 & 0.898 & 0.59225 \\
\hline \multirow[t]{5}{*}{ 关岭县 } & 2013 & 0.213 & 0.78 & 0.273 \\
\hline & 2014 & 0.486 & 1 & 0.486 \\
\hline & 2015 & 0.615 & 0.987 & 0.623 \\
\hline & 2016 & 0.467 & 1 & 0.467 \\
\hline & 平均值 & 0.44525 & 0.94175 & 0.46225 \\
\hline \multirow[t]{5}{*}{ 紫云县 } & 2013 & 0.771 & 1 & 0.771 \\
\hline & 2014 & 0.504 & 0.855 & 0.589 \\
\hline & 2015 & 0.647 & 0.961 & 0.673 \\
\hline & 2016 & 0.654 & 1 & 0.654 \\
\hline & 平均值 & 0.644 & 0.954 & 0.67175 \\
\hline
\end{tabular}

注：crste 代表综合效率（全要素生产率）, vrste 代表纯技术效率, scale 代表规模效率。 依据 DEA 效率分析结果，安顺市四个贫困县 2013-2016 年财政扶贫资金综合效率普遍较低, 近四年几乎都没有达到有效状态, 且规模效率均递减, 县级扶贫效果比贵州省及全国的效率 差。在观察的四个变量 2013-2016 年间, 综合效率平均值最高的是紫云县 (平均值为 0.644), 但该效率值偏低，表明紫云县 2013-2016 年只有 64. 4\%的扶贫资金能真正发挥作用，其余三 个贫困县资金综合效率更低，有更大占比的扶贫资金没有达到有效目的。

因此安顺市四个贫困县面临的共同问题是财政扶贫资金使用效率低，由上表 DEA 效率分析综 合效率无效性的主要原因是规模效率较低。研究年间规模效率平均值最高的紫云县规模效率 只有 0.67 , 换言之紫云县只需投入现有规模的 $67 \%$ 即可实现如今的扶贫效果。其次, 四个县 的纯技术效率数值上均接近 1 , 将近达到纯技术效率有效, 说明资金总体配置与管理水平等 技术层面对 GDP 增长贡献是合理的，纯技术效率不是扶贫资金总效率低的主要原因。

由安顺市四个贫困县 DEA 效率分解情况可总结出各县区效率值横向比较呈现出以下两项特 征: 一是综合效率和规模效率普遍较低, 且地区间效率差距较大; 二是纯技术效率的贡献水 平普遍较高, 且与综合效率变化趋势基本相同。以上结论揭示出近年来安顺市贫困县的扶贫 工作取得了明显成果，但是财政扶贫资金的利用效率较低，资金规模增加的同时扶贫生产率 却明显降低, 以至于影响到综合效率的提升，这一结论也证实了 “财政扶贫资金利用效率不 高, 规模效率递减” 是制约扶贫开发工作的瓶颈因素。

3.2 安顺市四个国定县财政扶贫资金使用效率定量评价

效率顾名思义是指产出与投入之间的比例关系。我们从定量层面研究扶贫资金的使用效率必 须明确扶贫资金的投入和产出的量化的指标。在产出方面, 孙群力 (2017) 等提出用单位财 
政扶贫资金减贫人口数量来反映财政扶贫资金使用效率，同时本文可得的安顺市财政扶贫资 金是按照因素切块法进行分配, 因此我们借鉴孙群力等的研究成果, 根据单位财政扶贫资金 减贫人口数进行评价扶贫资金的使用效率具有合理性。

我们假设某贫困地区第 $t$ 年的财政扶贫资金投入为 Ft (Funds)，第 $t$ 年的减贫人口为 Pt (Population)。贵州省财政扶贫资金为每年一月份下发到各县各户，同年十二月相关部门 进行扶贫成效的统计，考虑到扶贫资金的实施生效具有滞后性，资金投入到统计间相隔近一 年可视为资金投入与减贫之间的时间差。因此单位财政扶贫资金减贫率 RPT 的计算公式为:

$$
\mathrm{RPRt}=\mathrm{Pt} / \mathrm{Ft}
$$

（1）式表明，RPRt 指各地区单位财政扶贫资金成功实现的脱贫人口数量，其倒数则代表各 贫困地区的人均脱贫资金成本。我们可以理解为, RPRt 的数值越大, 即代表该地区的财政扶 贫资金使用率越高。

但是只计算某地区一年的 RPR 值不具有说服力, 有可能其他随机主客观因素对扶贫成效造成 影响。为了更加客观评价财政扶贫资金使用效率，尽可能排除其他因素的干扰，我们选取 2013-2016 年 (即实施精准扶贫战略后的四年) $\mathrm{n}$ 个地区的单位财政扶贫资金年平均减贫率作 为定量评价值。同时将安顺市四个贫困县与安顺市下属区县的西秀区、平坝区作横向比较, 与所在市级单位安顺市、同是贵州省地级市的毕节市进行纵向对比。

在具体评价某个地区的年平均减贫率时，考虑到不同年份的资金投入及减贫人口数量不尽相 同, 它们所占的权重也不一样, 我们选取某地区的减贫人口总数为 $\Sigma_{-1} \mathbb{F}_{\mathrm{t}}$, 统计年份为 2013-2016 年, 故 $n=4$; 财政扶贫资金投入总数为 ${ }^{2} F_{1} F_{t}, n=4$ 理由同上。在此构建出这些地 区单位财政扶贫资金年平均使用效率评价指标，计算结果见表 3 。

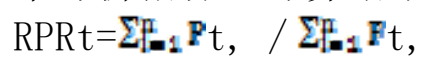

表3 贵州省-市（县/区）2013-2016年财政扶贫资金减贫效率比较

\begin{tabular}{cccc}
\hline 市县 $($ 区 $)$ & 财政扶贫资金 $($ 万元 $)$ & 减贫人口 $($ 人) & 单位扶贫资金脱贫人数 (人/万元) \\
\hline 普定县 & 25588.50 & 92300.00 & 3.61 \\
镇宁县 & 24717.00 & 63100.00 & 2.55 \\
关岭县 & 31578.00 & 88300.00 & 2.80 \\
紫云县 & 22564.00 & 85800.00 & 3.80 \\
西秀区 & 17124.63 & 43151.00 & 2.52 \\
平坝区 & 12666.50 & 31800.00 & 2.51 \\
安顺市 & 137613.37 & 418500.00 & 3.04 \\
毕节市 & 219484.00 & 1372700.00 & 6.25 \\
\hline
\end{tabular}

注: 由于数据的可得性, 并考虑到财政扶贫资金占扶贫资金主导地位, 这里仅统计了安顺市 部分地区及毕节市 2013-2016 年相关扶贫资金文件中的数据。

2013-2016 年安顺市四个贫困县每万元财政扶贫资金的减贫人数最多的是紫云县, 为 3.80 人, 占全市平均减贫效率的 $125 \%$; 最低的是镇宁县, 为 2.55 万人, 约占全市平均减贫效率的 $83.9 \%$ 。 安顺市四个贫困县的财政扶贫资金使用效率与安顺市总体水平比较较高，但四个县地区间差 距较大, 从定量角度肯定了我们在 DEA 验证中得出四个贫困县财政扶贫资金使用效率差距较 大的结论，但县区间效率差距较大，如关岭县和镇宁县效率较低，每单位扶贫资金的减贫人 数低于安顺市的平均水平。

与西秀区、平坝区进行横向比较，四个国定贫困县的财政扶贫资金使用效率略高。西秀区和 平坝区单位扶贫资金脱贫人数分别是 $2.52 ， 2.51$ 人，仅占安顺市平均水平的 $82.9 \%$ 和 $82.6 \%$ 。 相比之下，四个国定贫困县比西秀区和平坝区贫困程度更深。安顺市四个国定贫困县的财政 扶贫资金使用效率高于集中连片特困地区平均水平，也高于安顺市平均减贫效率。

为了从地级市层面进行纵向比较, 我们选择贵州省贫困村数量及农村贫困人口数量全省最高 的毕节市 (见表)。毕节市 2013-2016 年每万元财政扶贫资金减贫人数为 6.25 人, 超过安顺 
市同期平均减贫人数的两倍。根据 2015 年省统计局提供的数据, 毕节市有 115.45 万农村贫 困人口，安顺市只有 34.39 万；毕节市 2015 年贫困发生率为 $16.5 \%$, 而安顺市为 $13.7 \%$ 。可 以说, 毕节市的贫困覆盖面与安顺市相比更广, 社会经济发展更为落后。我们的计算分析显 示安顺市单位财政扶贫资金减贫人口远低于毕节市，这说明安顺市四个国定贫困县的财政扶 贫资金使用效率较低; 同时，整个安顺市的减贫水平都较低。

\section{4 结论}

基于上述实证研究，我们发现：安顺市四个国定贫困县财政扶贫资金使用效率与安顺的其他 县级单位和安顺市平均值相比处于较高水平。但与此同时无论是安顺市四个贫困县亦或是安 顺市总体平均减贫效率与毕节市相比都较低，这表明贵州省市县级地区间的财政扶贫资金使 用效率差距较大，部分地区的资金使用效率亟待提高。此外，毕节市的贫困规模，贫困程度 与安顺市相比更广且更深, 而安顺市四个国定贫困县的贫困状况也比两个集中连片特困地区 恶劣。我们可以将本次做实证的几个地区进行贫困程度进行排序: 安顺市两个集中连片特困 地区<安顺市 $<$ 四个国定贫困县<毕节市，同时根据本文的定量计算对财政扶贫资金使用效率进 行排序: 安顺市两个集中连片特困地区<安顺市 $<$ 四个国定贫困县<毕节市。这与我们定性研究 的结论一致，符合扶贫资金边际效用递减规律。

针对贵州省财政扶贫资金使用效率地区间差距较大的问题，考虑到财政扶贫资金是稀缺资源， 我们认为政府更应该重视优化财政扶贫过程中资金的规模及投向，从而提高资金使用效率， 充分发挥财政在精准扶贫中的主导作用。贵州省扶贫办等部门应该提取近年来扶贫工作投入 及产出的相关数据, 科学评价各市县的财政扶贫资金使用效率, 并基于评价结果根据当地实 际情况反思当前的扶贫政策措施，对资金的规模及投向进行有必要的调整。如：安顺市四个 贫困县的财政扶贫资金使用效率偏低，并由定性实证得出其综合效率低的原因是规模效率较 低。因此安顺市可通过对产业间的财政扶贫资金分配进行调整，并引进扶贫相应的技术、设 备的支持，从而提高规模效率，以期达到财政扶贫资金综合效率快速提高。

\section{Acknowledgements}

Thank for Guizhou university of finance and economics 2017 student scientific research grant project (project number: 2017ZXSY53)

\section{References}

[1]. Parvenu, Janna Tara. "Sustainability issues of interest-free micro-finance institutions in rural development and poverty alleviation. The Bangladesh perspective." theoretical and empirical researches in urban management, vol. 4, no. 2 (11), 2009, pp. 112-133. jester

[2]. De wit, hoop w. "urban poverty alleviation in Bangalore: institutional and community-level dilemmas." economic and political weekly, vol. 37, no. 38, 2002, pp. 3935-3942. jester

[3]. Paul, Samuel. "Mid-term appraisal of the sixth plan: why poverty alleviation lags behind." economic and political weekly, vol. 19, no. 18, 1984, pp. 760-765. jester

[4]. Birdman, prefab. "Efficiency, equity and poverty alleviation: policy issues in less developed countries." the economic journal, vol. 106, no. 438, 1996, pp. 1344-1356. Jester. 